\title{
In Search of Peaceful Future of the Asia-Pacific Maritime World: Formulating the Role of Indonesian Navy
}

\author{
Amarulla Octavian \\ Faculty of Defence Management, \\ Indonesian Defence University
}

\begin{abstract}
This article discusses how to formulate the role of Indonesian Navy as an effort to make peaceful future in the Asia-Pacific maritime world through military history perspective. Pacific War in World War II is perfect examples of how history could not be separated from the development of any nation in the world. No country could establish itself as a developed state without developing an internal awareness of its history. It is a record of the nation, either positive or negative, of one generation to be learned by the next one. Although our very existence is a result of the history of the past, the path of our future

Received:

20 December 2017

Accepted:

21 December 2017

Corresponding author:

roseauherve@gmail.com lies in our hands. It is important for Indonesia's current generation to excel positive contribution to the nation. This country is currently facing complex challenges, and the policy and strategy we will take would determine the face of our history in the future. Any mistakes in the formulation of policy and strategy would eventually have negative implication to our country; influencing our future.
\end{abstract}

Keywords: Asia-Pacific, maritime world, Indonesian Navy.

\section{Introduction}

History is one of the compulsory classes in professional military education of developed countries. It has a special position in military education as officers are exposed to numerous wars and battles that shaped the history of mankind, in which military personnel could gain many lessons learned from each war. The two wars of the last decade, Afghanistan and Iraq, have also become a part military history curriculum. The objective is simple; military officers could learn from the mistakes of wars in the past and to avoid the possibility of repeating such things.

In the past 113 years, strategies have been guilty of L'histoire se répète for two wars. The first is Operation Barbossa orchestrated by Adolf Hitler in 1941 to attack the Soviet Union end ended with the destruction of Wehremacht due to the Soviet's harsh and deadly winter in 1943. The 256.000 Nazi German troops, lead by General Frederich Paulus, surrendered to the Red Army on 31 January 1943 since their logistics were severely cut off. The Nazi's logistic transport, the Wehrmacht, couldn't pass through Soviet thanks to the winter. It was only time until their weapons, ammunitions and moral went down the hill. ${ }^{1}$

129 years prior to Operation Barbossa, Napoleon Bonaparte experienced a similar fate through a military campaign aimed to conquer the Russian Empire. Ignited by the Tsar

${ }^{1}$ www.history.com/this-day-in-history/von-paulus-to-hitler-let-us-surrender, accessed on 13 September 2013 . 
I of the Russian Empire's rejection to continue its blockade upon English goods, the campaign which started on 24 June 1812 was planned to end in only 20 days with 600.000 military personnel. In the beginning it was easy for Napoleon's troops to enter Russia since the Red Army retreated and did not give a worthy fight; nevertheless the change of weather han immense impact on the troops' logistics. ${ }^{2}$ As winter came, the Russian troops marched under Field Marshal Kutuzov who took the initiative to fight Napoleon's men. On 7 September 1812 both troops fought in Borodino without victory and 108.000 lives perished. After the battle in Borodino, Napoleon's men arrives in Moscow on 14 September 1812 only to find an abandoned town where its people had fled and buildings were destroyed and burned by the Russians. It was a devastating blow since there was o place to take cover againts Russia's long and cold winter. They began to withdraw from Russia on October 1812 with a huge price to pay by the troops. Both Hitler and Napoleon shared a similar mistake.

The second one happened in the beginning of the $20^{\text {th }}$ century as Western countries and Japan were rivaling one another over dominance in East Asia. Japan wanted to dominate the control of the seas in order to fight wars on Asia's soil; therefore its forst objective wa to cripple the RussianFleet in port Arthur at the Yellow sea. On 1904, led by Admiral Heihachiro Togo, the Japanese Armada launched a torpedo assault at night towards Russian Fleet at Port Arthur. This sudden attack crippled the naval based and damaged two Russian warships badly. ${ }^{3}$ The great battle was continued the next morning and small ones around the port continued until May 1904 and finally the Russian surrended on 2 January $1905 .^{4}$

The 36-year old Admiral Isoroku Yamamato practiced the same tactics of naval assault. On 7 December 1941, the Imperial Japanese Navy launched a surprise attack upon numerous US military facilities in Hawaii, including the Pearl Harbor naval base. The armada, consisted of six aircraft carriers, two batlle ships, three cruisers, nine destroyers, and eight tanker ships left its naval base and led by Vice Admiral Chuichi Nagumo, sailed to Pearl Harbor without any radio contact. The attack damaged and destroyed around 20 US warship and 188 aircraft where more than 2.000 US Navy sailors and aviators died. ${ }^{5}$ Not only did the attack caused severe losses upon the assets and lives of the United States Navy, it also showed that the Japanese Armada was able to operate without being detected as the fleet sailed from Japan to the north part of the Islands of Hawaii. Togo and Yamamoto used the same tactics; surprise attacks.

These wars are perfect examples of how history could not be separated from development of any nation in the world. No country could establish itself as a developed state without developing an internal awareness of its history. It is a record of nation, either positive or negative, of one generation to be learned by the next one. Although our very existence is a result of history in the past, the path of our future lies in our hands.

\footnotetext{
${ }^{2}$ Napoleon's personnel was cut around 150.000 men on September 1812 due to desertion after the logistic were cut off before his army was involved in the desicive battle against Russia.

${ }^{3}$ Russia sent her naval fleet under the leadership of Admiral Zinovy Rozhestvensky with 28 warship from the Baltic Fleet heading to Vladivostok, Russia's Pacific Fleet was paralyzed after the Battle of the Yellow Sea on 10 August 1904 and the Battle of Ulsan on 14 August 1904. The $18.000 \mathrm{~nm}$ sail from the Baltic to Yellow Sea had immense influence upon the readiness of this Fleet the long journey has made most of the ships were not ready for battle as they entered Tsushima Strait on 27-28 May 1905. This condition was known and was well utilized by Admiral Togo by preparing precise strategy and tactics to cripple Russia's fleet. By implementing the crossing the T tactics, 89 Japanese warship of many types were able to sink and paralyze most of Russia's warships.

${ }^{4}$ http://id.wikipedia.org/wiki/Perang_Rusia-Jepang, accessed on 2 September 2013.

5http://id.wikipedia.org/wiki/Pengeboman_Pearl_Harbor, accessed on 2 September 2013.
} 
It is important for Indonesia's current generation to excel positive contribution to the nation. This country is currently facing complex challenges, and the policy and strategy we will take would determine the face of our history in the future. Any mistakes on the formulation of policy and strategy would eventually have negative implication to our country; influencing our future. It is likely that current generation could be recorded as the failed one to promote a better future for Indonesia.

History is not only a domestic issue; it is also has a strong influence over the relations between countries. We have to seen numerous conflicts and disputes between or among countries are a result of historical relations. On the other hand, some have also experienced great wars in the past; however they could take a step forward and form strong alliances.

At present time we have seen conflicts and disputes among countries due to historical claims. The south China Sea dispute is a very current example where China based its claim over this strategic waters based on the pages of its land's history. The concepts of nation-state and international law are often not compatible with this historical claim of style.

History is marked by changes will change itself is history's very own characteristic. As we learn more about theoritical claims, every nation has experienced changes in the size of its territory; either downsized or expanded. Turkey, to mention one example, had its territory as far as Central Europe during the Ottoman Empire. The country now has a much smaller territory compared to its history of the great empire and conqueror.

It would be logical to state that historical claims over territory would only bring upon conflict and dispute in relation among states. Territory is dynamic; hence having historical claims as the only approach over territory claim will only create a world far from peace and stability. History could not be use as a reason for any country to claim a certain area as it may start conflict between or among states.

\section{Reviewing the History of Asia Pacific}

Asia Pacific is a region of dynamic history as one observes World War I and II. During World War I, most countries in the region were under the colonization of the West, except for a number of countries such as Japan and China. Some were at their infancy of nationality awareness that would be the foundation of a nation-state, while others were still far from such process of understanding.

To be more accurate, Japan was the only country where its territory wasa free from any western occupation because most of China's eastern coast was still under the control of the West. Post World War I saw Japan took control of most of the small island in the Pacific that were once under the Germans. Both World Wars have changed the geography and geopolitics of the region dramatically; some experienced a reduction in their territories and some expanded.

The world witnessed the birth of new countries in the Asia Pacific region post World War II (see Figure 1) after gaining independence from western colonization. This process was not without difficulties because Europe only divided their colonies and power in the region based on their own interests and agreements. They did not consider the cultural aspects of the land they colonized. The Malays, for example, now lives in four different countries in Southeast Asia; Indonesia, Malaysia, Singapore and Brunei Darussalam.

The challenges these new countries faced were enormous. Some countries are rich in diverse ethnicity and culture, whereas ignited many domestic conflicts. We could see that in Indonesia, Malaysia, Myanmar and Singapore. Others have same ethnicity and religion at least have the majority of each and were able to reduce internal conflicts. Nevertheless the 
challenges did not stop there; these countries inherited issues of territories as new borders and maritime boundaries were not easily accepted by their neighboring countries.

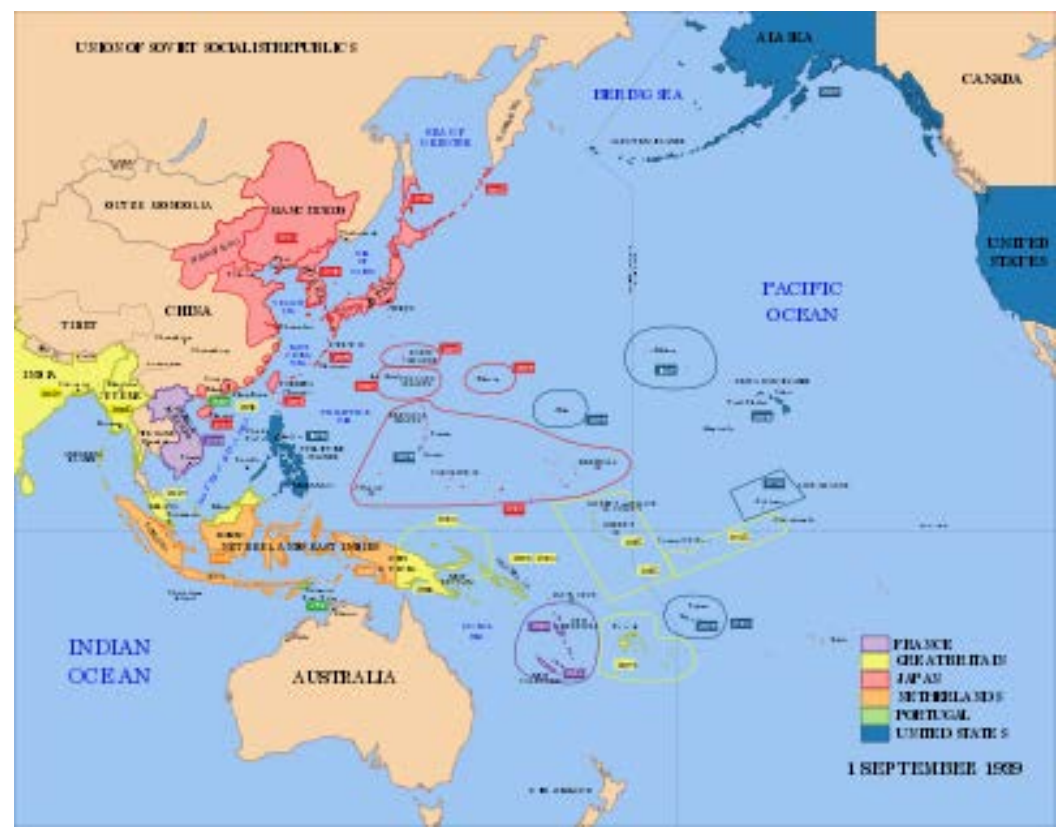

Figure 1. The Map of the Asia Pacific Region Prior to World War II ${ }^{6}$

The cold war era brought about challenges and issues to these countries that were still very young and were struggling to find their own balance in the world. At the same time, the main players of the Cold War, the United States and the Soviet Union, were doing everything in their power to take as many as countries they can to join their side. The new countries in Asia Pacific were not out of such effort. The pages of the world's history have written numerous battles, conflicts and wars as results of this clash of titans.

The Korean War is one of example of proxy war between the United States and Soviet Union; the last supported by China. Other examples include the Vietnam War, Afghanistan War and the War in Cambodia. These wars have been taken millions of human lives, as the same other internal conflicts in Asia Pacific, which are actually the implications the rivalry of two superpowers. A number of rebellions in Indonesia, such as PRRI and Permesta, also involved the United States.

The Cold War was a brutal test to the territorial integrity and the national unity of these new countries. Some were able to pass the tests; however some were divided and eventually could reunite again, either through peaceful or violent means. In short, the conflicts within the region during this era were implications from the rivalry of the West and East Blocks.

Post Cold War era saw a conversion of conflicts from inter-state to intra-state conflict. We have been some intra-state conflict during Cold War; however it became more prominent after the era ended. The roots of this conflict include dispute over natural resources and the rivalry of different ethnicity within state by using violent means. These intra-state conflicts were still influenced by external elements, both direct and indirectly, due to similar ethnicity or religion. The region's stability was endangered by these conflicts.

On the other hand, inter-state conflict was still alive in this era as a result of the past's failure to resolve conflict potentials in peaceful ways. This conflict revolved around 
territorial claims in which the disputed areas usually rich in natural and economical resources, such as oil and gas, one prominent example is the South China Sea dispute.

We are in the age where the world is facing the threat of energy, food and water shortage. In this context history has been often utilized as a source to justify a country's claim over a territory area.

\section{Maritime Conflicts in Asia Pacific}

After reviewing the history of this region, it would be interesting to now focus on a number of Asia Pacific's ongoing maritime conflicts, including the disputes in Bering Sea, the Island of Kuril, and others.

The Bering Sea is located between Russia and Alaska and the dispute began when the United States bought Alaska from Russian Empire, an area of 600.000 square miles in 1867. It was worth US\$ 7.2 million. ${ }^{7}$ In 1990 the Soviet Union and the United States Strengthened this agreement through the Bakes-Shevardnadze Agreement.

Issues started to emerge when the Soviet Union collapsed and Russia once again rises in the international community. Russia denounced the legality of the agreement in 1990 since Edward Shevardnadze, the Soviet Union's Minister for Foreign Affairs during that year, did not represent Russia's interest. The agreement itself could only be applicable if it were to be ratified by the Russian parliament. ${ }^{8}$

Russia refused to ratify the agreement and demanded the United States to revise it. Its reasons include oil and gas reserves in the sea as well as its effort to secure its fishing quota near Alaska. According to the US Mineral Management, the Bering Sea is estimated to have 24 billion barrel of oil and 126 trillion cubic feet of natural gas reserves. ${ }^{9}$ The United States fishing sector could take in around 2 million metric tons of fish annually. ${ }^{10}$

It is not a surprise that America has also rejected Russia's demands. Russia then took a position that there is no definitive agreement on both countries' marine boundaries; although international law is more in favour of America's position. ${ }^{11}$ This marine dispute remains alive between both countries regardless of the absent of military tension in the disputed area.

The next example is the Islands of Kuril which came under the control of the Soviet Union just a few days before World War II ended. The Soviet Union attacked the Japaneseoccupied islands after the last declared its involvement in the Pacific war after the battles in Europe ended in May 1945. This resulted in the absence of peaceful agreement between the two countries to end World War II due to the dispute over the Kuril Islands. ${ }^{12}$ Japan demanded the return of the islands since it believes Russia has taken the islands away during World War II, while Russia rejected the idea of such action. This dispute has become a thorn in the bilateral relation between Japan and Russia until today.

${ }^{7}$ Vlad M. Kaczynski, “US-Russian Bering Sea Marine Border Dispute: Conflict over Strategic Assets, Fisheries and Energy Resources”, Russian Analysis Digest, 20/2007, p. 2.

${ }^{8}$ Kaczynski, "US-Russian Bering Sea Marine Border Dispute: Conflict over Strategic Assets, Fisheries and Energy Resources", p. 2.

${ }^{9}$ Kaczynski, “US-Russian Bering Sea Marine Border Dispute: Conflict over Strategic Assets, Fisheries and Energy Resources", p. 3.

${ }^{10}$ Kaczynski, "US-Russian Bering Sea Marine Border Dispute: Conflict over Strategic Assets, Fisheries and Energy Resources", p. 3.

${ }^{11}$ Kaczynski, "US-Russian Bering Sea Marine Border Dispute: Conflict over Strategic Assets, Fisheries and Energy Resources", p. 2.

${ }^{12}$ Vlad M. Kaczynski, “The Kuril Islands Disputed Between Russia and Japan: Perspectives of Three Ocean Powers", Russian Analysis Digest, 20/2007, p. 6. 
The Islands of Kuril has an extensive reserve of fishing resources. The economy of Russian Far East depends highly on the contribution of the islands' fishing sector, which covers fishing, processing as well as crab catching, consumed mostly in the area and the rest exported to nearby countries.

Japan also has a maritime dispute with China over the Senkaku Islands (in Japanese) or Diaoyu (in Chinese), a string of uninhabited islands in the East China Sea. For hundreds of years the islands have become a part of Japan's territory. Nevertheless China claims them part of its historical empires and so legally part of modern China's territory.

In the past year the world has seen how the Senkaku Islands dispute has taken center stage in the global news with the deployment of China's civilian patrol ship and maritime patrol aircraft. Japan reacted by sending its Coast Guard ships and F-15 fighter jets. Scientific research has proven the islands' rich gas and oil reserves; ${ }^{13}$ these facts could only push the level of dispute even further.

Another of Japan's maritime dispute involves the Takeshima or Dokdo Island dispute with South Korea. Historically this island is within Japan territory and is acknowledge by the United States under the 1951 San Frasisco Agreement. On the other hand South Korea claims the island as part of its maritime territory and has persuaded America to convince Japan to release its claim over the island; the United States has rejected such request. ${ }^{14}$ In June 1954 South Korea populated the Island, naming it as Dokdo; hence a dispute with Japan came into the picture.

Currently South Korea has a number of military infratructures established to secure the island, and the bilateral relations between the two countries have experinced much tension over the island known to the West as the Liancourt Rocks. The presence of military forces in the island is also to secure the abundan natural resources of oil, gas and fishing reserves.

Another well-known maritime conflict in Asia Pacific is the South China Sea dispute among six claimant states: Brunei, Phillipines, Malaysia, Vietnam, China, and Taiwan. Most of the claimant states based their claims on the interpretation of the UNCLOS 1982, except for China and Taiwan with their historical claims. These countries have occupied a number of areas or islands in the South China Sea, and even have infrastructures established, such as aircraft runways and naval bases military activities.

ASEAN's effort to attain peaceful solution to this dispute through the Declaration of Conduct (DoC) in the South China has yet to bear fruits of labor. It is possible to say that the DoC has failed since some of the claimant states, also signatories of the DoC, have violated the declaration. Indonesia has proposed the draft of the Code of Conduct (CoC), however it has not seen significant progresses. The dispute has become more complex since the interests of extra regional power over the safety of navigation along the disputed waters have come into the picture; the United States as on of the countries.

The South China Sea connects East Asia with the Indian Ocean. Besides being the main choice for energy transportation from the Middle East to East Asia, it is also the route for shipping East Asia products to regions along the Indian Ocean and Europe. Its economic value is extremely high, and the failure of the region to manage the dispute would eventually have strong political and economic implications for not only Southeast Asia, but also the regions in the world. In the last development we have seen how the South China Sea dispute has slowly transformed into an arena of two global major powers; China and the United States.

${ }^{13}$ Read, news.nationalgeographic.com/news/energy/2012/10/121026-east-china-sea-dispute/, accessed on 29 August 2013.

${ }^{14}$ Read, www.mofa.go.jp/region/asia-paci/takeshima/position.html, accessed on 29 August 2013. 


\section{The Role of the Indonesian Navy to Improve Maritime Security Stability}

ASEAN has been Indonesia's primary interest in its foreign policies for a long period of time. For a such as ASEAN and the ASEAN Regional Forum or ARF have always focused on three steps of mechanism: confidence building measure, preventive diplomacy and conflict resolution. Through these for Indonesia invites all related parties of Southeast Asia's security and stability to sit down together and discuss over solution to current issues and put forward cooperation above conflict.

Indonesia's current foreign policy lies on the Natalegawa Doctrine; the dynamic equilibrium. It is the realization of the President's directive on Indonesia's foreign policy of "sailing on the turbulent sea". In short, it is Indonesia's effort to become a balancer among regional powers.

Today it is very clear that both the United States and China have taken efforts to strengthen their influences among countries in the Asia Pacific region and ASEAN members. Indonesia has seen how both major powers are trying to gain more influence through the sales of weapon systems and other forms of assistance to the Indonesian National Defence Forces (INDF) or TNI. It is understandable since for long Indonesia has played a central role among ASEAN member countries and its actions have become guidance to neighboring states.

The ARF was established as a dialogue forum on Asia Pacific's security issues among ASEAN's 10 members countries and their 10 Dialogues Partners in 1994. Since its first meeting, the frum has been active in managing regional security stability. Even though it is not a binding-like establishment, it has managed to handle numerous security regional issues. Currently the annual ARF meeting along with its working group discusses a number of common security issues, such as maritime security, counter terrorism, North Korea nuclear issue, and natural disasters. The ARF has also organized a multinational military exercise on maritime security threats, terrorism and natural disasters in Manado, Indonesia in 2011.

Still in the level of ASEAN, the member countries' naval cooperation lies in the informal corridor of cooperation since ASEAN is not a defense pact. Nevertheless in practice the agreements of ASEAN's Chief of Navy have been proven to be effective in "binding" all enganged parties.

Indonesia has proposed the importance of ASEAN naval cooperation through the annual ASEAN Navy Chiefs' Meeting (ANCM). As the initiator, Indonesia eventually plays a more central role in the ANCM forum; similar to Indonesia's role in ASEAN. Hence, the Indonesian Navy is currently preparing the first ever multinational naval exercise for ASEAN Navies to conduct cooperation on the operational area. The Multilateral Naval Exercise will be held in the end of March 2004 in the Natuna Islands and focuses on naval cooperation on disaster relief operations.

Prior to the exercise next year, the Indonesian Navy will also host the International Maritime Security Symposium in Jakarta, December 2013. These activities are formulated to ensure a stronger ASEAN naval cooperation in the practical level as a response to common challenges in the region; piracy and armed robbery against ships, maritime terrorism, human smuggling, environmental issues, safety of navigation, energy security, natural disasters, and others. Both of the agendas are the mandate of the ADMM Plus and ANCM in order to invite all related parties and to promote the implementation of CoC in South China Sea.

Another interesting point is the success of the Malacca Strait Patrol (MSP) as the response of Indonesia, Malaysia and Singapore on the increased maritime security threats 
along the Straits of Malacca in 2004. The Chief of Armed Forces of the three littoral states along with the Chiefs of Navy agreed to conduct coordinated patrols on the Straits of Malacca since 20 July 2004 with the consent of the three governments.

The MSP consist of three elements of operation. The first is the Malacca Strait Sea Patrol (MSP) where the assets of three navies patrol along their respective maritime boundaries in the Straits of Malacca. Second is Eyes in the Sky (EiS), a maritime air patrol participated by the Air Forces of the three littoral states; Thailand soon joined in. The third is the Intelligence Exchange Group (IEG), a forum for the three navies to conduct intelligence sharing to secure the busy strait. The existence of IEG is very crucial in the trilateral cooperation since the willingness to have intelligence sharing is one of the parameters to evaluate the the level of cooperation among countries.

According to the reports of the International Maritime Bureau (IMB), the number of piracy cases in the Straits of Malacca has dropped significantly from 38 in 2004 to zero in 2011.15 ReCAAP has also reported a decrease in piracy cases in the strait from 35 cases in 2005 to zero in 2011.16 These numbers are proof that the international community acknowledges Indonesia's claims on the success of the MSP.

The success of the MSP in securing the straits of Malacca provides ASEAN with a model of security cooperation on a practical level. As maritime security challenges and disputes are of common interest among ASEAN member countries, the proposal of the establishment of ASEAN Maritime Patrol (MSP) could be the form of cooperation needed in the region.

There are three important components in the AMP. The first is the ASEAN maritime operations. In the waters of Southeast Asia, each state has its sovereign rights in their respective territorial waters. As for international water such as the South China Sea, ASEAN member states may conduct coordinated or joint patrol in regard to the interest of all members in a voluntary manner.

The second is ASEAN operations, which could involve the operation on Naval Aviation as well as Air Force aircraft of ASEAN member states. Operation sectors will be decided through mutual agreement. Similar to the ASEAN maritime operations, it will also acknowledge and respect the airspace all ASEAN member states during their air patrol. Nevertheless the aircraft of both Naval Aviation and Air Force of ASEAN member states could conduct ISR operations along the international waters in accordance to their national interest.

The last one is the ASEAN intelligence operations. The two previous operations would not be possible without the support of the intelligence community that has moved from information sharing to the level of information exchange. Such change requires standardization on equipment, personnel competence, mechanisms and procedures. If each ASEAN member state could establish its own National Maritime Command and Control Centre as its Information Sharing Centre, it would enable it to integrate their network and connection with another ASEAN member states' Information Sharing Centre; therefore foster and strengthen intelligence cooperation.

Southeast Asia's maritime security is a common responsibility shared among ASEAN member countries; a concept that respect the sovereignty of each country. Therefore out of crucial for ASEAN to improve the quality and intensity of its maritime security cooperation in accordance to the establishment of the ASEAN Politico-Security Community. Maritime security has been listed as one of the focuses of the cooperation under this community. At

\footnotetext{
${ }^{15}$ Read, www.thejakartapost.com/news/2012/01/03/hijacked_tugboat-rescued-singapore-strait.html, accessed on 13 May 2013, 10.30 Jakarta time.

${ }_{16}$ Read, www.thejakartapost.com/news/2012/01/03/hijacked_tugboat-rescued-singapore-strait.html, accessed on 13 May 2013, 10.30 Jakarta time.
} 
the same time, the development in the South China Sea dispute has pushed ASEAN to further its maritime security cooperation as one of the ways to ensure the global community that this dispute will not transform into an open conflict.

Through these initiatives and proposals, the Indonesian Navy is ready to take the role in leading ASEAN Navies in their naval cooperation as part of the contribution of the navies to regional maritime security stability. Thus, the Indonesian Navy necessitates the support from many domestic institutions and agencies in its endeavor. It is crucial to strengthen the synergy between the Indonesian Navy and related stakeholders. In the future the Indonesian Navy will initiate other proposals and initiatives to ensure regional maritime security stability.

\section{Conclusion}

Our human civilization's main threats currently derive from a number of non-traditional threats, including energy, food, and water security. As land resources become more limited from time to time, humans are pushed to look at the seas and oceans as the next promising source of important natural resource for the sake of our survival. These resources have become the roots of current conflicts or disputes in the maritime domain.

History has played an important role in today's existing conflicts and disputes, resulting in an ongoing hostility between and among states. Even though many out of the box ideas have been shared in order to resolve these inter-state conflicts, often they were defeated by narrower interest in the national level. In this globalized world we have seen more and more shared interests among states that should be a valid reason to cooperate on reducing conflicts and war potentials. We must break away from the shackles of history to be free from conflicts, disputes and wars.

Many countries have used nationalism and economic interests as their reasoning for conflict and war. Clausewtiz's thinking in his On War (1832): “.... We see, therefore, that war is not more merely an act of policy but a true political instrument, a continuation of political intercourse carried on with other means" still has a special meaning in the back minds of our decision makers. Nevertheless we should look back at our history, where it is clear how our past has taught us that wars for the pursue of nationalism and economic interests would always claim an immense price of tens of millions of lives and the massive economic destruction and losses bore by at least two generation.

A new interpretation on nationalism and economic interests is urgent for today's globalized world since both could no longer become the source of justification in any kind of conflict or war. Eliminating conflict and war might be a utopia for us, but reducing them would be a necessity for our future generation. Nationalism and economic interests could not be used as a political reason for conflict and/ or war; the antithesesis of Clausewtiz's ideas. The globalization era we live in requires us to accept international law as the new world order as well as the win-win solution for territorial conflict or dispute.

The Indonesian Navy is fully aware UNCLOS 1982 necessitates amendments, nevertheless we also believe that it is the best reference the international community has to resolve a maritime dispute. In the last decade, the Indonesian Navy has played a significant role in maintaining regional maritime security stability. Its success in securing the Straits of Malacca from maritime security threats by cooperating with navies of littoral states is not reason for complacency. It will continue to enhance its role in the region through multilateral breakthroughs and initiatives to strengthen confidence building measures to prevent future conflicts. 


\section{References}

Kaczynski, Vlad M., "The Kuril Islands Disputed Between Russia and Japan: Perspectives of Three Ocean Powers", Russian Analysis Digest, 20/2007.

Kaczynski, Vlad M., "US-Russian Bering Sea Marine Border Dispute: Conflict over Strategic Assets, Fisheries and Energy Resources", Russian Analysis Digest, 20/2007.

en.wikipedia.org/wiki/Pacific War, accessed on 13 September 2013.

http://id.wikipedia.org/wiki/Pengeboman_Pearl_Harbor, accessed on 2 September 2013.

http://id.wikipedia.org/wiki/Perang_Rusia-Jepang, accessed on 2 September 2013.

news.nationalgeographic.com/news/energy/2012/10/121026-east-china-sea-dispute/, accessed on 29 August 2013.

www.history.com/this-day-in-history/von-paulus-to-hitler-let-us-surrender, accessed on 13 September 2013.

www.mofa.go.jp/region/asia-paci/takeshima/position.html, accessed on 29 August 2013.

www.thejakartapost.com/news/2012/01/03/hijacked_tugboat-rescued-singapore-strait.html, accessed on 13 May 2013, 10.30 Jakarta time. 